\title{
A HISTORICAL OVERVIEW OF NUCLEAR ENERGY REGULATIONS IN ASEAN
}

\author{
Ridoan Karim \\ Abu Bakar Munir
}

\begin{abstract}
The consistent rise in the prices of oil, coal, fossil fuels and on the other, the lack of natural gas reserves has indicated the struggle of ASEAN for energy demand, which is eventually going to persist in future. Consequently, due to the scarcity of fossil fuels, oil and natural gas resource, nuclear energy surfaces as a palatable strategic option for ASEAN's future development agenda. However, a successful nuclear power program entails an extensive infrastructure. The control of nuclear energy is one of the prime concerns of science, industry, and politics. Henceforth, the study of this paper is based on secondary sources where a qualitative research is conducted to analyse the historical and regulatory issues relating to the nuclear energy generation in ASEAN. The study combines doctrinal normative and comparative historical and legal analysis. Consequently, one of the prime researches of the paper will skirt around the topic related to the public awareness and embroilment of such nuclear energy development in ASEAN. The paper recommends ASEAN to adopt a comprehensive energy law ought to be realigned to consider more noteworthy emphasis on sustainability, developing technical, financial, and institutional constraints and promoting public awareness and involvement associated with the generation of nuclear energy.
\end{abstract}

\section{Introduction}

Nuclear energy has emerged as an issue of global and local importance, propelled in large part by increased costs of fossil fuels, rising energy needs, concerns over inefficiencies in the energy mix, security of energy supply, climate change, its cleanness as less carbon polluting than fossil fuels, raw material availability, technicians and scientist's interests etc. Nuclear power supplies a large amount of the world's electricity needs. Likewise, the case of ASEAN is no exception.

The consistent rise in prices of oil, coal, fossil fuels and the lack of natural gas reserves has meant that ASEAN's struggle for energy demand is going to persist in future. ${ }^{1}$ The environmental impact of this phenomenon should not be discounted either. ${ }^{2}$ Under these circumstances, nuclear energy is an attractive strategic option for the regional government of ASEAN community. This reflected in the Vietnam's, Indonesian and Malaysian government's decision to construct nuclear power plants to stimulate the ongoing economic growth and meet consumer and industry demands. ${ }^{3}$

However, it is imperative that a nuclear energy program cannot gain success without a comprehensive regulatory regime. ${ }^{4}$ Hence, this study examines the prospects for building a stronger regional normative framework in promoting nuclear safety and security and preventing proliferation of nuclear weapons in the region through a historical analysis of nuclear regulatory regime. In our historical and regulatory discussion, the study simultaneously argues that there remain challenges in utilizing the best from nuclear energy because of the regulatory and technical issues relating to it. The existing nuclear infrastructure issues, if they remain unaddressed, can pose challenges to these ASEAN norms.

The significance of this research study is that it provides an opportunity to revisit research concerns on the topical subject of nuclear power which, paradoxically, has not been thoroughly addressed in ASEAN and make fresh and original legal and scholarly 
contributions, focused on the region, that add to the corpus of knowledge in the nuclear field globally. This study thus introduces and develops new knowledge on the history of effective regulation of nuclear power for electricity generation in ASEAN. Therefore, the paper analyses the nuclear regulatory framework in ASEAN through a historical assessment and recommends to adopt a comprehensive energy law ought to be realigned to consider more noteworthy emphasis on sustainability.

Although many assessments of atomic energy written by the environmentalists are highly persuasive, however, they often neglect the regulatory, social, historical and ethical dilemmas respecting the generation of nuclear power. On the other hand, books, thesis and reports written by nuclear proponents only focus purely a scientific assessment of fission generation of electricity and almost always ignore the social and regulatory aspects of energy decision-making. As this research attempts to provide a brief legal, regulatory and historical analysis on the generation of nuclear power in ASEAN and avoid unsubstantiated assertions, such study undoubtedly will stand as a major reference work on the subject.

\section{Brief History of Nuclear Energy: Lessons on Regulation}

Before analyzing the ASEAN's nuclear energy regulation and describing its history, it is very important to see how the nuclear energy regulations emerged world-wide. Thus, this section of the study will emphasize on the history of emerging nuclear regulatory regime.

Nuclear and radiation related technology dates back to Roent-gen's discovery of the ray in 1895 and Becquerel's discovery of natural radioactivity in $1896 .{ }^{5}$ The great step forward, however, came in 1905 with Albert Einstein's Special Theory of Relativity. ${ }^{6}$ Largely because of Einstein's discovery, nuclear concepts were already well-developed by the late 1930's. Afraid lest Hitler be the first to develop an atomic bomb, Einstein wrote President Roosevelt and told him it might be possible for the US to build such a weapon. ${ }^{7}$

The quest for nuclear power for mitigating energy needs started not long after the revelation in the mid twentieth century that radioactive components, for example, radium, discharged massive measures of energy, as per the standard of mass-energy equality. In any case, method for tackling such energy was awkward, in light of the fact that serious radioactive components were, by their extreme nature, brief (high-energy discharge is corresponded with short half-lives).

Nonetheless, the vision of bridling "nuclear energy" was very solid, despite the fact that it was downplayed by such fathers of atomic material science like Ernest Rutherford as fantasy or unrealistic. ${ }^{8}$ This circumstance, be that as it may, changed in the late 1930s, with the experimental success of atomic splitting. In 1932, James Chadwick found the neutron, which was quickly perceived as a potential apparatus for atomic experimentation in light of its absence of an electric charge. ${ }^{9}$ Thereafter the improvement of Nuclear energy starts.

'Nuclear technology' is a broad term encompassing both fission and fusion. Since the only type of nuclear power currently used for commercial generation of electricity is fission, the analysis of this study is limited to a discussion of fission technology.

The history of nuclear fission technology, widely employed in medicine and in the generation of electricity, is in large part the history of the atomic bomb. ${ }^{10}$ Both nuclear weapons and reactors produce energy by fissioning uranium or plutonium. ${ }^{11}$ In a fission reactor, the energy release is completely controlled and used to produce electricity. In a weapon, the energy release is largely uncontrolled. ${ }^{12}$ Both uses of fission, however, produce substantial amounts of radioactivity.

The reasons for beginning to develop fission reactors in the 1940's and 1950's were that the military wanted bombs and the government hoped to take advantage of its new technology for peace, as well as wartime, purposes. The years 1939 to 1942 has been characterized as the era of "control by secrecy ... initiated by scientists" with military support 
after the discovery and recognition of fission in $1939 .{ }^{13}$ The "control by secrecy" 14 was continued further by the military in close collaboration with scientists from 1942 to 1946. The goal of this control was the manufacture of the nuclear bomb.

Tromans ${ }^{15}$ argues that the technology produced weapons-grade plutonium and electricity generation was an "accidental by-product." ${ }^{16}$ In 1945, the first atomic bomb was created in USA. ${ }^{17}$ Nuclear research into the atom, development of the first nuclear reactor and atomic bomb were all largely unregulated. ${ }^{18}$

After witnessing the devastation of atomic bomb, the scientists and scholars have agreed upon to use such technology only for peaceful purposes. Near the twilight of World War II, the protection of international peace and prevention of world war which the League of Nations failed to achieve was reactivated. ${ }^{19}$ On 25 April 1945, fifty (50) countries met in San Francisco, USA and committed themselves to create the UN to harmonize their actions on upholding international peace and safety, consolidating sociable relations among nations and social development, higher living quality and standards and human rights. ${ }^{20}$

Ironically, during this UN process, 'Little Boy' and 'Fat Man' atomic bombs were unleashed on Japan at Hiroshima and Nagasaki on 6/8/1945 and 9/8/1945 respectively. The UN was set up on 24 October 1945, barely 2 months after the 1945 events at Hiroshima and Nagasaki. ${ }^{21}$ The US was the only country that possessed atomic weapons then. Worldwide concern about the potential benefits and grave dangers of atomic energy led to urgent global calls to regulate nuclear energy.

The May-Johnson Nuclear Bill was initiated in the US in $1945 . .^{22}$ The UN convened its first General Assembly on 10 January 1946, after only two months in existence. ${ }^{23}$ The first Resolution of the maiden UN General Assembly, passed on 24 January 1946, was on the need to regulate atomic energy. ${ }^{24}$ It recognized the United Nations Atomic Energy Commission (UNAEC) to inter alia manage the issues raised by the revelation of nuclear energy and make particular proposition for the end from national deadly implements of nuclear weapons. ${ }^{25}$

UNAEC in 1946 proposed a plan (i.e., the Baruch Plan) under which the US was to destroy its atomic weapons and any atomic energy development, globally, will be subject to UN controls which will permit only nonviolent usage of atomic energy ${ }^{26}$ Lack of consensus led to the demise of UNAEC in $1952 .{ }^{27}$

Scientists were optimistic about the 'Atoms for peace' program; it also provided a non-warlike rationale for continuing the development of nuclear energy. Thus, the government was able to develop commercial reactor and, at the same time, obtain the weapons-grade plutonium as a reactor by-product. ${ }^{28}$

Although it has been born-again, renamed "atoms for peace", and offered a hand of fellowship into the UN peaceful family, yet it's paradoxical dual nature - devastatingly deleterious, but yet, serving exceedingly useful peaceful purposes - frame its identity. In its incipient days (in 1950s) nuclear energy was touted to have been the elixir for natural and social plights of humanity: such as poverty, hunger, epidemics, incurable diseases like cancer, etc. It is thus argued that international lawmaking during this time mainly targeted thwarting the US-USSR unclear arms race, disarmament, and the edification of a system under which nuclear weapons will be non-proliferated. It was hinged upon the certitude that nuclear power, if used for peaceful intent, could provide a cheaper and safer alternative to endemic sources of energy. ${ }^{29}$ Thus, the era of nuclear energy production began.

Introduced atomic limit at first rose moderately rapidly, ascending from less than 1 gigawatt (GW) in 1960s to $100 \mathrm{GW}$ in the late 1970s, and eventually reaching $300 \mathrm{GW}$ in the late 1980s. Since the end of the decade of 1980s, overall limit has risen a great deal more gradually, achieving $366 \mathrm{GW}$ in 2005. This is further enhanced in 2010s. Now its capacity 
exists in the TWh region, with potential to rise exponentially due to the inherent nature of fission reactions.

Up to 1946, research into nuclear energy and its exploitation was still under military control and shrouded in secrecy in the US, Russia (USSR), UK, France, China and a few other countries. In 1946, the US rejected the May-Johnson Nuclear Bill and passed the Atomic Energy Act (or the McMahon Act) under which control over research and production of nuclear energy was taken from the US military and was rather given to the self-governing, civilian-governed Atomic Energy Commission. ${ }^{30}$ But the Act retained a tight government monopoly on atomic endeavors. The Act was drafted to "cover a program that was primarily concerned with building an Atomic arsenal", ${ }^{31}$ and provided safeguards to prevent other States from becoming nuclear weapon states. The US stated in its 1946 law that, without safeguards there might be no trade of data with different countries concerning the utilization of nuclear energy for mechanical [i.e. peaceful] purposes. ${ }^{32}$

The UK also passed a similar Act (the Atomic Energy Act of 1946) with the Ministry of Supply having responsibility of nuclear material. ${ }^{33}$ Section 1 of the UK Act, gave the Minister of Supply the general power to "promote and control the development of atomic energy." " American President Dwight Eisenhower, in 1953, delivered his famed "Atom for Peace' speech at the UN General Assembly. Calling the attention of the world community to the devastating horrors atomic weapons can wreak on mankind, he urged the international community to regulate the use of atoms for pacific resolutions only. ${ }^{35}$

In 1954, soon after this speech, US and UK reformed their nuclear energy laws and, respectively, passed the Atomic Energy Act, 1954, ${ }^{36}$ which superseded the existing 1946 Atomic Energy laws in the US and the UK, and permitted sequestered involvement in nuclear energy expansion and encouraged peaceable usage of nuclear energy under strict government control. ${ }^{37}$

In June 1954, the USSR connected the first nuclear power plant to an electricity grid Obninsk near Moscow to provide 5MW of electricity to residences and businesses. ${ }^{38}$ The project was part of the effort to showcase the civilian and peaceable usage of nuclear energy. The reactor was thus christened 'peaceful atom' in Russia. This came in less than half a year following the Atom for Peace speech by Eisenhower. Great Britain, in 1956, opened an atomic energy reactor in Calder Hall. ${ }^{39}$ It was the pioneering nuclear power station worldwide capable of generating electricity on a commercial basis. Therefore, the nuclear technology for energy production was getting its popularity world-wide at the late nineties.

The first decade of this millennium's imperative of dropping greenhouse gas emissions, tied with serious apprehensions over energy security, resulted in a spirited revival of interest in nuclear power in several countries. However, Fukushima brought a lot policy change towards nuclear energy in Germany, where US showed a lot concerns, but they do not really change much to their policies. ${ }^{40}$ Japan's position remained same but they are more talking about the use of safe nuclear power. ${ }^{41}$ Scholars pointed out that there is one common feature of all three severe nuclear accidents: in 1979 the Three Mile Island incident, NPP of Chernobyl in 1986, and finally the Fukushima Daichi Nuclear Power Plant disaster in 2011. In all cases the main culprit of failure of the cooling system. ${ }^{42}$

The atomic misfortune at Fukushima Daiichi NPP has had noteworthy effect on closeby groups because of radioactive tainting of land and groundwater, and long haul departure of individuals from their homes, ranches, organizations and groups. Researchers likewise contend that not the catastrophic event, but rather the administrative failures added to the most exceedingly awful atomic accident since Chernobyl and clarifies how the easy connection deliver between the administration, controllers and nuclear administrators, the joined part of NISA as an industry promoter and controller, and the spinning entryway amongst officials and enterprises had since a long time ago undermined the limit of Nuclear 
Industrial Safety Agency (NISA) as a guard dog for nuclear safety-security. ${ }^{43}$ In this way, the world now knows redesigning and reinforcing a nuclear administrative framework is not discretionary but rather basic to keep the following core meltdown.

After a thorough discussion on the historical overview of the international nuclear regulatory regime, the study will focus on ASEAN in the next section. The analysis of next section will help the readers to understand the historical background of the nuclear regulatory regime in ASEAN and what are loop holes that still exist in their regime.

\section{Nuclear Energy in ASEAN}

Though, currently ASEAN does not have any operating nuclear plants, however, several member countries like Vietnam, Thailand, Indonesia and Malaysia has an active program aimed at achieving that end. Vietnam's heavy reliance on fossil energy has contributed to severe air pollution in its major cities, while at the same time presenting a major financial challenge because the country's expanding economy demands a growing amount of energy. As such, the Vietnamese government has clearly stated its commitment to pursue a nuclear program in spite of the Fukushima accident. Like others in the region, Vietnam has reacted to the accident by stressing the necessity of ensuring the highest possible level of nuclear safety measures. The Vietnamese Ministry of Foreign Affairs echoed this policy in March 2011 considered nuclear energy as a top priority and described that the fission technology is particularly important in the context of climate change and natural disasters. ${ }^{44}$ However, in 2016, Vietnam's National Assembly voted to abandon plans to build two multi-billion-dollar nuclear power plants with Russia and Japan, after officials cited lower demand forecasts, rising costs and safety concerns. ${ }^{45}$

The prospective nuclear power plants were capable of generating 4000MW worth of power with assistance from Russia and Japan that have been scrapped by Vietnam and the prime reason cited for the cancellation is paramount danger to the environment. ${ }^{46}$ Even though the two plants would be the largest nuclear power plants in South East Asia and promised to slake the energy crisis that Vietnam faces, it was eventually decided that the cons far outweigh the pros. ${ }^{47}$

Unlike Malaysia, Thailand has announced a freeze on constructing the country's first nuclear power plants. ${ }^{48}$ In practice, however, this decision has not had any practical implication as the Thai government has never taken any tangible step toward construction. Among other factors, Thailand's government has lacked internal cohesion and faced social and political instability since the September 2006 military coup led to the overthrow of its prime minister. Thailand has since suffered from political uncertainty thanks to the large and active pro-Thaksin movement. ${ }^{49}$ While the central government is in control of the country, the absence of a safe and secure environment to realize a nuclear sector situation will likely discourage nuclear-technology suppliers from supplying Thailand if and when it decides to pursue its nuclear program.

By the same token, the decision of the Philippines to discard plans to activate the shelved Bataan Reactor had practical implication for the region's nuclear energy sector. The reactor was built in the late 1970s, but was not commissioned because of litigation concerning bribery and safety deficiencies. ${ }^{50}$

Interestingly enough, Indonesia has not yet decided to give up its envisaged nuclear program. In fact, the Indonesian government has dismissed the Fukushima accident as a strong reason for shelving its nuclear program. On March 18, 2011, Adiwardojo, the head of nuclear energy development at Indonesia's National Nuclear Energy Agency, said that concerns about a disaster similar to Fukushima were misplaced because Indonesia's future plants would use technology that was far more advanced. ${ }^{51}$ Of course, there is still opposition within the Indonesian experts regarding the nuclear power plants. Yet what is important is 
that Indonesia cannot discard its nuclear power option given its rapidly depleting fossil energy resources. The fact that it is no longer an OPEC member and has become an oil importer to meet its domestic needs could well make Indonesia more interested in a nuclear option.

\section{Development of Nuclear Energy Policies in ASEAN}

The catastrophe of Fukushima brought a lot policy change regarding nuclear energy at the moment when the nuclear power industry was presumed as a highly prospectus for the future generation of energy in Asia. ${ }^{52}$ It was significant to note that the Fukushima disaster change the public perception towards nuclear energy and ASEAN countries also started to revise their strategic policies of nuclear power generation. Though there were a lot of safety concerns, the policymakers in Southeast Asia choose to carry out the nuclear energy development programs with more sincerely and carefully. The government of the countries in Southeast Asia perceived nuclear power as an alternative source of energy which eventually can help to achieve the energy security and mitigate the effects of climate change. ${ }^{53}$ Vietnam, Indonesia and Malaysia took serious concern to establish nuclear power plants in order to ensure their energy supplies. It is undeniable that nuclear power in their energy mix can reduce the overdependence on fossil fuels and can make their energy supplies more secure, affordable and environmentally sustainable. (see Table 1).

Table 1 ASEAN Electricity Generation by Source (percentage)

\begin{tabular}{|l|l|l|}
\hline & 2011 & 2035 \\
\hline Coal & 32 & 48 \\
\hline Oil & 44 & 28 \\
\hline Gas & 10 & 2 \\
\hline Nuclear & 0 & 2 \\
\hline $\begin{array}{l}\text { Renewables } \\
\text { (hydro, geothermal, } \\
\text { bioenergy, and others) }\end{array}$ & 14 & 20 \\
\hline Total & 100 & 100 \\
\hline
\end{tabular}

Source: International Atomic Energy Agency. ${ }^{54}$

It was projected that Vietnam will be the first country to introduce nuclear energy in the region's energy mix by 2020 after the construction of its first nuclear power plant. However, their recent suspension on nuclear projects make a vague situation concerning such technology in Vietnam. There exists serious opposition towards the Indonesia's nuclear power programs, however, government have already taken the initiative to introduce an experimental nuclear power reactor soon enough to understand their capability to become a nuclear energy producing country. ${ }^{55}$ In the meantime, Malaysia has taken the steps to conduct research on the feasibility on exploiting nuclear energy. The government of Malaysia seems to care the public concerns on fission technology and they devote themselves to uphold the public acceptance of nuclear projects. It is important to note that the people in ASEAN not fear nuclear energy only because of the Fukushima, however, they cite the failure of the Philippine's government to start the first nuclear energy production of the region.

Philippine was supposed to produce nuclear energy in 1984 after the construction of the Bataan Nuclear Power Plant (BNPP), however, the plant never saw the light of the energy production. Though, the government has already spent around $\$ 2.3$ billion, nevertheless, BNPP has never been commissioned because of the administrative corruption, managerial failure and safety concerns. ${ }^{56}$ The geographical position of BNPP was also not suitable as it is located near an active volcano and a fault line. The Philippine's failure to introduce such technology in their energy mix had serious negative implications to other ASEAN member 
states towards the fission technology. That is where the ASEAN policymakers questioned on the issues of the regionalization of nuclear energy governance in the ASEAN region. It is imperative that the introduction of nuclear energy in ASEAN presents both prospects and challenges. The challenges broadly includes the issues concerning better coordination, sharing of best practices, regional capacity building, and the strengthening of nonproliferation norms.

The Southeast Asia Nuclear Weapon-Free Zone 1995 Treaty (the Bangkok Treaty) was the first articulated regional norms in ASEAN concerning the nuclear safety and nonproliferation issues. The main objective of the treaty is to apprehend each state to develop, manufacture, or possess nuclear weapons, however, at the same time, the treaty consists with provisions that ensure the rights of member states to use the nuclear strength for peaceful purposes, in particular for economic development and social progress. Fundamentally, the treaty establishes the general framework governing the usage of nuclear technology.

The significant regional norms that have been established by the Treaty are the following: a state pursuing nuclear energy must

1. use nuclear material and facilities within its territory exclusively for peaceful purposes;

2. subject its nuclear program to rigorous safety assessment, conforming to guidelines and standards recommended by the International Atomic Energy Agency (IAEA) for the protection of health and minimization of danger to life and property;

3. inform fellow members, if requested, of the outcome of the safety assessment;

4. uphold the international nonproliferation system through strict adherence to the Treaty on the Non- Proliferation of Nuclear Weapons and the IAEA safeguard system; and

5. dispose of radioactive wastes and other radioactive material in accordance with IAEA standards and procedures. ${ }^{57}$

At the ASEAN Ministers of Energy Meeting (AMEM), the ASEAN policymakers discussed about the importance of the fission technology in order to enhance the economic growth of the region. They also focused to ensure the regional safety issues that could have serious implications because of the usage of nuclear energy. In the 2012 "Phnom Penh Declaration on ASEAN: One Community, One Destiny," ASEAN leaders agreed to "develop a coordinated ASEAN approach that would contribute to global undertakings to improve nuclear safety, in cooperation with the IAEA and other relevant partners, as well as promote and uphold IAEA standards of safety and security in the development of nuclear energy for peaceful use." 58

Policymakers of ASEAN also emphasized the importance to develop a "network amongst nuclear regulatory bodies in Southeast Asia which would enable regulators to exchange nuclear related information and experiences on best practices, enhance cooperation and develop capacities on nuclear safety, security and safeguards." ${ }^{59}$ Hence, in 2011 the ASEAN Network of Regulatory Bodies on Atomic Energy (ASEANTOM) conducted several meetings for the purpose to decide the best possible norms and ways to use the nuclear energy for the betterment of the regional citizens. ${ }^{60}$

The main objective of this network is to promote the mutual benefits. For example, the network deliberately promised to work on the enhancement of the regulatory capacity by collaborating the technical experts and proposed to provide training to create sufficient human resource with the proper knowledge which can deal with different aspects of nuclear energy technology. It is inevitable that sharing the experience and relevant experiences among the ASEAN member states in regulating nuclear activities will surely ensure nuclear safety, security, and safeguards. The policymakers also emphasized to work on nuclear 
activities by exchanging information in order to promote transparency within the region. The member states found useful solutions to work together in nuclear emergency preparedness and response, as well as radiation monitoring in the region. ${ }^{61}$

These steps surely presents that the ASEAN recognize the importance of upholding the regional norms on peaceful use of nuclear energy through regional cooperation. However, a regional framework on regulations and policies still is not adequate to deal with the complex issues of nuclear energy. The major challenge that may ASEAN face is the lack of technical knowledge and experience which can provide the best means to utilize nuclear energy.

In addition, challenges such as insufficient human resources, inadequate regulatory and legislative frameworks, and institutionalized national radioactive waste management strategies can create a huge barrier on implementing nuclear technology practically. Essentially, the objectives of the regional goals established by the Treaties cannot be implemented if a member state is unable to institutionalize a comprehensive regulatory framework.

Repeatedly, licensing process for the nuclear power plants may look complex and troublesome if the proper legislations in the region does not comply with the nuclear power plant licensing regimes of the member states. Hence, a competent nuclear regulatory body which can typically addresses proliferation concerns by inspecting and verifying the licensing regime is much needed. In order to ensure all applicable safety and security requirements related to material control and accounting, information security, waste management, emergency preparedness, fire safety, radiation safety, and physical protection, a comprehensive nuclear regulatory body in the region needed to be introduced. ${ }^{62}$ Nuclear facilities should always be monitored in order to maintain safe and secure energy production. There remain nuclear proliferation risks if the monitoring bodies do not perform their task efficiently.

\section{Legislative and Regulatory Frameworks}

The stakeholders and policymakers relating to nuclear energy technology have always claimed that necessary improvements have been taken place in the nuclear industry after the Fukushima catastrophe in order to maintain a safe and secure energy production. However, in case of nuclear safety and liability, there remain a lot legislative loopholes which the ASEAN member states should consider. It is very important for the nuclear newcomers in Southeast Asia to learn lessons from the mistakes of the experienced nuclear energy producing county in order to facilitate their own technology safe and secure. Such emphasization has also been addressed by the IAEA's director-general, Amano Yukiya, who repeatedly mentioned the importance of an independent regulatory body that can lead to greater transparency and improves public acceptance. ${ }^{63}$

Fukushima teaches us again and again about the importance of an independent nuclear safety regulatory body. The 1994 Convention on Nuclear Safety and the IAEA Safety Requirements call for the establishment of a regulatory body and the need for its separation, or independence, from the promoters of nuclear technology, such as government ministries. ${ }^{64}$ Independent regulatory body is made mandatory by the IAEA in order to ensure that policies of the government does not initiate conflict with the safety and security issues of fission technology.

Though Vietnam possess high interest to produce nuclear energy, they still lack with proper legislative framework on regulatory independence. The Vietnam Agency for Radiation and Nuclear Safety (VARANS) is currently serving as a nuclear regulatory body. The body is under the administration of the Ministry of Science and Technology (MoST). ${ }^{65}$ Noteworthy, the process to develop an independent regulatory agency was initiated by the 
Ministry in 2012. Japan's Ministry of Economy, Trade, and Industry signed an agreement to enhance the technical and safety competence of Vietnam's nuclear regulatory body. One of the proposed amendments to Vietnam's Atomic Energy Law is to make VARANS an effectively independent regulatory body, since at present it is only "partly independent" under MoST, the leading agency promoting nuclear energy in Vietnam. ${ }^{66}$ The independency of VARANS's is limited to regulating radioactive sources and materials, mostly for industrial, educational, and medical applications. Therefore, regulating the safety and security aspects of NPP does not fall under the functions of the agency and there remains a lot regulatory challenges to address. The government has yet to act on proposed amendments to VARANS and it remains uncertain whether a Vietnamese regulatory agency fully independent of ministries promoting nuclear energy can be established.

In Indonesia, contrary to what the IAEA prescribes, there is no Nuclear Energy Implementing Organization (NEPIO) to lead and manage the effort to consider and develop an NPP program. ${ }^{67}$ Instead, several institutions such as the National Nuclear Energy Agency (BATAN), BAPETEN, the Ministry of Energy and Mineral Resources, the Ministry of Environment, and the Ministry of Research and Technology carry out separate functions in preparing for the establishment of NPPs. ${ }^{68}$ This arrangement may compromise the regulatory impartiality of BAPETEN since it is part of the multiagency NPP preparatory program and may be involved in activities leading to possible establishment of an NPP.

In an ideal situation, BAPETEN should have objective regulatory oversight of these preparatory activities. Another issue in Indonesia is the delegation of NPP-related responsibilities to different agencies, which requires coordination. The absence of a dedicated steering committee signifies a lack of commitment in pursuing NPPs because although BATAN is the primary institution working on nuclear power as it reports directly to the president, it does not have any authority over other agencies. More importantly, BAPETEN itself admitted that Indonesia's legislative framework is not yet in full compliance with IAEA standards. ${ }^{69}$ And while existing legal frameworks govern the potential use of nuclear power, they require amendments to incorporate some international conventions, such as the Joint Convention on the Safety of Spent Fuel Management and the Safety of Radioactive Waste.

In Malaysia, the main legislation relating to NPPs is the Atomic Energy Licensing Act 1984 (Act 304), which includes detailed provisions on radioactive materials. ${ }^{70}$ In 2011, Malaysia Nuclear Power Cooperation (MNPC) was established as a NEPIO. MNPC is under the supervision of the Prime Minister's Department and assumed the functions of the Nuclear Power Development Steering Committee. ${ }^{71}$ The Atomic Energy Licensing Board (AELB) is the assigned nuclear regulatory body in Malaysia. However, it is also part of the Nuclear Power Development Steering Committee chaired by MNPC, which may compromise its regulatory independence since it is involved in the preparatory initiative to set up an NPP in the country. The board is also an agency attached to the Ministry of Science, Technology, and Innovation, which actively promotes the use of nuclear energy, and a member of the MNPC board of directors. In accordance with IAEA recommendations, a regulatory body should be completely independent of any government ministry that has an interest in the establishment and operations of NPPs.

\section{Nuclear Safety and Security Measures}

In terms of institutionalizing nuclear safety and security measures, the three countries have managed to introduce several initiatives that may strengthen their commitment to upholding the nuclear $3 \mathrm{~S}$, though some challenges have been identified by observers and even by state agencies. For instance, Vietnam has no prior experience in utilizing nuclear energy in terms of scientific and technical knowledge as well as nuclear emergency management. The concept of safety culture even within the regulatory body is not explicitly defined since 
public awareness of safety culture remains low. Until today, a deep understanding of issues related to the safety of nuclear power projects among Vietnamese stakeholders, from government agencies to scientists and communities, is still very limited. ${ }^{72}$

Several Vietnamese nuclear experts have voiced concerns over nuclear safety and the absence of an independent regulatory body, coupled with widespread corruption and transparency issues, and a record of poor safety standards. ${ }^{73}$ The Fukushima nuclear disaster raised concerns over Vietnam's capacity to administer and regulate nuclear energy. Vietnam is also in the vulnerable position because of the climate change and a country facing natural disasters continuously every year might face problems to address the safety issues of generating nuclear energy. Rising sea levels and stronger typhoons are particularly the threats of Vietnam's nuclear energy program. ${ }^{74}$ The coastline of Ninh Thuan (where the power plant will be established) is also vulnerable to tsunamis potentially originating from a strong tremor in the South China Sea. Because of these risks, the government recently took the decision not to set up its NPPs in Ninh Thuan, however, such decision has not made any permanent solutions. Government of Vietnam still looking for the other options in case of setting their nuclear projects.

In Indonesia, the plans for NPP development draw concern both domestically and internationally due to the frequent occurrence of natural disasters such as volcanic eruptions, earthquakes, tsunamis, floods, and landslides (National Agency for Disaster Response 2012). Realizing the implications of such geological vulnerability, BATAN has conducted site selection processes based on IAEA guidelines-BCR no. 5/2007 on the Safety Provision for Site Evaluation for a Nuclear Reactor - and best practices from other countries. ${ }^{75}$

Several proposed sites for the NPP, such as Muria (Central Java province) and Banten (West Java province), have been found to be located in seismically active zones. ${ }^{76}$ Bangka Island, east of Sumatra Island, is now the preferred site for the first NPP. It sits outside the Ring of Fire and has a low risk of natural disasters. ${ }^{77}$ BAPETEN has not received any formal application from BATAN, however, suggesting that the plan to construct an NPP on Bangka Island is still at the feasibility study stage. In order to prepare for nuclear accidents, Indonesia has held a number of nuclear emergency exercises and drills, and Fatmawati Hospital in South Jakarta is a designated referral hospital for nuclear emergencies. Reflecting on recent natural disaster responses performed by the Indonesian National Board for Disaster Management (BNPB), challenges in interagency coordination including division of authority, chain of command and control, and mobilization of resources remain the source of subpar responses.

In anticipation of such challenges, in August 2014 BAPETEN formed the Indonesian Center of Excellence on Nuclear Security and Emergency Preparedness, ${ }^{78}$ a special platform where BAPETEN, BATAN, police, customs, the foreign ministry, and intelligence services communicate and coordinate their efforts for nuclear security and emergency responses. ${ }^{79}$ To strengthen nuclear security and reduce nuclear proliferation risks, Indonesia has radiation portal monitors at several ports of the archipelago. ${ }^{80}$

Since Malaysia is located outside the Pacific Ring of Fire and typhoon belt, it is less susceptible to hazards such as earthquakes, volcanic eruptions, and typhoons. ${ }^{81}$ Floods and landslides are among the few natural disasters that typically hit Malaysia. ${ }^{82}$ In 2009 , Malaysia completed NPP siting guidelines and in 2011, five candidate sites were identified. The possible construction of a Malaysian NPP is still at a very early planning stage, as site selection was made based on digital mapping and no fieldwork has been carried out to date. ${ }^{83}$

To boost emergency response and preparedness, AELB established a Nuclear Emergency Team, and first responders are located at the northern, southern, eastern, and Sabah-Sarawak parts of Malaysia. ${ }^{84}$ AELB has regularly conducted national radiological emergency response drills, such as the National Radiological Emergency Drill, in the event of 
a transport accident. It has also conducted a National Field Exercise on Research Reactor Emergency Response, and a Table Top Exercise on Research Reactor Emergency Response in $2007 .{ }^{85}$ To protect its nuclear facilities and adhere to nonproliferation norms, Malaysia is forging a close partnership with the United States through the Global Threat Reduction Initiative. ${ }^{86}$ In February 2012, four Radioactive Sources Category 1 Facilities in Malaysia were assessed under the GTRI framework. ${ }^{87}$ Malaysia also takes part in the Global Initiative to Combat Nuclear Terrorism (GICNT). As part of its commitment to this initiative, Malaysia hosted a tabletop exercise with Australia, New Zealand, and the United States in $2014{ }^{88}$

\section{Recommendations and Conclusion}

ASEAN has distinguished atomic power as a piece of sustainable energy framework. After a large portion of a century of fruitful advancement, experiencing superb achievement and eagerness and indistinct feedback, nuclear power has made a substantial commitment to human advancement. No other energy innovation has such an across the board widespread demand, spanning from nuclear material science, physical sciences, chemistry, biology, medicine, and other disciplines like software engineering, psychiatry, or pharmacy. The education to utilize atomic innovation has been aggregated amid the most recent fifty years and must be managed promote irrespective of the part nuclear energy will play in $21 \mathrm{st}$ century onwards. The safety and security of the at present existing nuclear establishments and particularly the new ones that are being manufactured and anticipated that would be inherent in the creating scene, which will frankly rely on upon how countries, governments, and regional powers learn to implement, design, safeguard, exchange and further develop nuclear learning and talent around the world.

In sum, we believe that any nuclear energy program is a long-term commitment that should be expected to take decades, from planning and construction to operation, waste management, and capacity building. It is a sophisticated, uniquely hazardous and proliferation-prone technology that requires rigorous planning. Vietnam, Malaysia, and Indonesia have already institutionalized several measures that adhere to the region's normative framework on the peaceful use of nuclear energy. Yet the safe development of nuclear power in Southeast Asia faces hurdles to ensure adherence to nuclear $3 \mathrm{~S}$ norms, including on nonproliferation. Regional cooperation is the key to achieving adherence, and with the establishment of an ASEAN Community by the end of 2015, consensus on nuclear energy-related issues is possible. Member states will, however, have to work around concerns about noninterference in domestic affairs, giving priority to shared concern and interest in a nuclear-safe and nuclear weapons-free ASEAN. The paper recommends ASEAN to adopt a comprehensive energy law ought to be realigned to consider more noteworthy emphasis on sustainability, developing technical, financial, and institutional constraints and promoting public awareness and involvement associated with the generation of nuclear energy. 


\section{Notes}

${ }^{1}$ Sopitsuda Tongsopit, Noah Kittner, Youngho Chang, Apinya Aksornkij, and Weerin Wangjiraniran, Energy security in ASEAN: a quantitative approach for sustainable energy policy, Energy policy, Vol 90, 2016, pp. 60-72.

${ }^{2}$ Ibid.

${ }^{3}$ Nicholas Fang, Towards a Regional Nuclear Energy Safety Regime in Southeast Asia, In Mapping State and Non-State Actors' Responses to Nuclear Energy in Southeast Asia, 2017, pp. 15-26.

${ }^{4}$ Yi-Chong Xu, The struggle for safe nuclear expansion in China, Energy Policy, Vol 73, 2014, pp. 21-29.

${ }^{5}$ Merrill Eisenbud and Thomas F. Gesell, Environmental Radioactivity from Natural, Industrial AND Military Sources: From Natural, Industrial and Military Sources, Academic press, 1997.

${ }^{6}$ Arthur I Miller, Albert Einstein's special theory of relativity, Includes a translation by AI Miller of A. Einstein's" On the Electrodynamics of Moving Bodies, Springer-Verlag New York, 1998, pp. 74.

${ }^{7}$ Lawrence S Wittner, The struggle against the Bomb, Stanford University Press, 1993.

8 Ernest Rutherford, LVII. The structure of the atom. The London, Edinburgh, and Dublin Philosophical Magazine and Journal of Science, Vol 27, No 159, 1914, pp. 488-498.

9 James Chadwick, The existence of a neutron, In Proceedings of the Royal Society of London A: Mathematical, Physical and Engineering Sciences, Vol. 136, No. 830, 1932, pp. 692-708.

${ }^{10}$ Kristin Shrader-Frechette, Nuclear power and public policy: The social and ethical problems of fission technology, Springer Science \& Business Media, 2012.

${ }^{11}$ Ibid.

${ }^{12}$ Ward F. Whicker and Vincent Schultz. Radioecology: nuclear energy and the environment, Vol. 1, Boca Raton, FL: CRC press, 1982.

${ }^{13}$ Dean C Dunlavey, Government Regulation of Atomic Industry, University of Pennsylvania Law Review, Vol 105, No. 3, 1957, pp. 295-373.

${ }^{14}$ Ibid.

15 Stephen Tromans, Nuclear law: the law applying to nuclear installations and radioactive substances in its historic context, Bloomsbury Publishing, 2010.

${ }^{16}$ Ibid.

${ }^{17}$ David Fischer, History of the International Atomic Energy Agency: The First Forty Years, 1997.

${ }^{18}$ David Kauzlarich and Ronald C. Kramer, Crimes of the American nuclear state: At home and abroad, Upne, 1998.

${ }^{19}$ Samuel Eliot Morison, History of United States Naval Operations in World War II: The Battle of the Atlantic, September 1939-May 1943, Vol. 1, University of Illinois Press, 2001.

20 UN at a Glance: The History of the United Nations, available at http://www.un.org/en/aboutun/history/index.shtml

${ }^{21}$ Paul Boyer, By the bomb's early light: American thought and culture at the dawn of the atomic age, Univ of North Carolina Press, 2005.

${ }^{22}$ B.B Ferencz, Defining international aggression, the search for world peace: a documentary history and analysis, Oceana Pubns. Vol. 2, 1975

${ }^{23}$ Ibid.

${ }^{24}$ Linda A Malone, The Chernobyl accident: a case study in international law regulating state responsibility for transboundary nuclear pollution, 1987.

25 United Nations General Assembly, Retrieved January 27, 2017, from http://www.worldlii.org/int/other/UNGA/1946/

${ }^{26}$ David Tal, The American nuclear disarmament dilemma, 1945-1963, Syracuse University Press, 2008.

${ }^{27}$ Ibid.

${ }^{28}$ Mason Willrich, Global politics of nuclear energy, Praeger Publishers, 1971.

${ }^{29}$ Elena Molodstova, Nuclear Energy and Environmental Protection: Responses of International Law, Pace Envtl. L. Rev, Vol. 12, 1994, pp. 185.

${ }^{30}$ Gene B Karpinski, Federal Preemption of State Laws Controlling Nuclear Power. Geo. LJ, Vol 64, 1975, pp. 1323. 
${ }^{31}$ Dean C Dunlavey, Government Regulation of Atomic Industry, University of Pennsylvania Law Review, Vol 105, No. 3, 1957, pp. 295-373.

${ }^{32}$ US Atomic Energy Act, 1946, Section 10(a)(1)

33 John Simpson, The independent nuclear state: the United States, Britain and the military atom,Springer, 1983.

${ }^{34}$ Atomic Energy Act, 1960

35 Samuel Obeng Manteaw, 'Evaluating Ghana's Regulatory Readiness for Safe Nuclear Power Generation Using International Law and Comparative Study Approaches.' PhD Thesis, University of Ghana, 2012.

36 Stephen Tromans, Nuclear law: the law applying to nuclear installations and radioactive substances in its historic context, Bloomsbury Publishing, 2010.

37 The United Kingdom Atomic Energy Authority Act 1954; see also the US Atomic Energy Commission Act 1954

${ }^{38}$ From Obninsk Beyond: Nuclear Power Conference Looks to Future, Retrieved January 27, 2017, from https://www.iaea.org/newscenter/news/obninsk-beyond-nuclear-power-conference-looks-future

${ }^{39}$ Michael L. Dockrill and John W. Young, British Foreign Policy, 1945-56, Springer, 1989.

${ }^{40}$ Lincoln L Davies, Beyond Fukushima: Disasters, nuclear energy, and energy law, 2011.

${ }^{41}$ Ibid.

${ }^{42}$ Qiang Wang, Xi Chen and Xu Yi-chong, Accident like the Fukushima unlikely in a country with effective nuclear regulation: Literature review and proposed guidelines, Renewable and Sustainable Energy Reviews, Vol. 17, 2013, pp. 126-146.

${ }^{43}$ Tudor Ionescu,, Masterarbeit/Master's Thesis, (2017).

${ }^{44}$ Mary Beth D. Nikitin, Mark Holt and Mark E. Manyin. US-Vietnam Nuclear Cooperation Agreement: Issues for Congress, Current Politics and Economics of South, Southeastern, and Central Asia, Vol. 23, No. 1, 2014, pp. 23.

${ }^{45}$ Alistair DB Cook and Sofiah Jamil, Nuclear Energy Security and the Policy Environment in Southeast Asia, In Mapping State and Non-State Actors' Responses to Nuclear Energy in Southeast Asia, 2017, pp. 1-14.

${ }^{46}$ Ibid.

${ }^{47}$ Ibid.

${ }^{48}$ Subhash Kumar, Assessment of renewables for energy security and carbon mitigation in Southeast Asia: The case of Indonesia and Thailand, Applied Energy, Vol 163, 2016, pp. 63-70.

${ }^{49}$ Manas Chatterji, Technology transfer in the developing countries, Springer, 2016.

50 Alistair DB Cook and Sofiah Jamil, Nuclear Energy Security and the Policy Environment in Southeast Asia, In Mapping State and Non-State Actors' Responses to Nuclear Energy in Southeast Asia, 2017, pp. 1-14.

${ }^{51}$ Subhash Kumar, Assessment of renewables for energy security and carbon mitigation in Southeast Asia: The case of Indonesia and Thailand, Applied Energy, Vol 163, 2016, pp. 63-70.

52 International Energy Agency, Southeast Asia Energy Outlook: World Energy Outlook Special Report, Paris: International Energy Agency, 2013.

${ }^{53}$ Victor Nian and S. K. Chou, The state of nuclear power two years after Fukushima-The ASEAN perspective, Applied Energy, Vol. 136, 2014, pp. 838-848.

${ }^{54}$ International Energy Agency, Southeast Asia Energy Outlook: World Energy Outlook Special Report, Paris: International Energy Agency, 2013.

55 Miklos Gaspar, New IAEA Collaboration Centre to Bring Nuclear Diagnostics, Testing and Inspection Technologies to Southeast Asia, 2015, www.iaea.org/newscenter/news/new-iaeacollaboration-centre-bring-nuclear-diagnostics-testing-and-inspection-technologies-southeast-asia.

${ }^{56}$ Norimitsu Onishi, A Nuclear Plant, and a Dream, Fizzles, New York Times, February 13, 2012, www.nytimes.com/2012/02/14/world/asia/bataan-nuclear-plant-never-opened-now-a-tourismsite.html?_r=0.

${ }^{57}$ Association of Southeast Asian Nations, Treaty on the Southeast Asia

Nuclear Weapon-Free Zone, 1995, www.asean.org/news/item/treaty-on-thesoutheast-asia-nuclearweapon-free-zone. 
58 Joint Ministerial Statement of the 30th ASEAN Ministers of Energy Meeting, Phnom Penh, Cambodia, September 12, 2012, www.asean.org/news/asean-statement-communiques/item/jointministerial-statement-of-the-30thasean-ministers-of-energy-meeting-amem.

${ }^{59}$ Ibid.

${ }^{60}$ Mely Caballero-Anthony and Julius Cesar I. Trajano, The State of Nuclear Energy in ASEAN: Regional Norms and Challenges, Asian Perspective, Vol 39, No. 4, 2015, pp. 695-724.

${ }^{61}$ Victor Nian and S. K. Chou, The state of nuclear power two years after Fukushima-The ASEAN perspective, Applied Energy, Vol. 136, 2014, pp. 838-848.

${ }^{62}$ US Nuclear Regulatory Commission, NRC's Support of U.S. Nonproliferation Objectives in the Licensing of Enrichment and Reprocessing Facilities, 2015, www.nrc.gov/reading-rm/doccollections/fact-sheets

/nonproliferation.pdf.

${ }^{63}$ Amano Yukiya, Atoms for Peace in the 21st Century, Transcript of speech delivered at the Energy Market Authority Distinguished Speaker Programme, Singapore, January 26, 2015, www.iaea.org/newscenter/statements/atoms-peace-21st-century-1.

${ }^{64}$ Sagan, Scott D. Sagan and Edward D. Blandford, Learning from a disaster: Improving nuclear safety and security after fukushima, Stanford University Press, 2016.

${ }^{65}$ Azlina Mohammad Jais and Najwa Hassan, Protection of people and environment from radiation risk through good regulatory practice, In AIP Conference Proceedings, Vol. 1799, No. 1, 2017.

${ }^{66}$ Ibid.

${ }^{67}$ Mely Caballero-Anthony, Alistair David Blair Cook, Julius Cesar I. Trajano, and Margareth Sembiring, Can ASEAN develop a robust nuclear energy regime?, 2014.

${ }^{68}$ International Energy Agency, Southeast Asia Energy Outlook: World Energy Outlook Special Report, Paris: International Energy Agency, 2013.

${ }^{69}$ Geni Rina Sunaryo, Development of Nuclear Power Programme in Indonesia, Presentation at the 5th Nuclear Power Asia Summit, Kuala Lumpur, Malaysia, January 27, 2015.

${ }^{70}$ A Bidin, Nuclear Law and Malaysian Legal Framework on Nuclear Security." Paper presented at the Singapore International Energy Week, Singapore, October 31, 2013, www.esi.nus.edu.sg/docs/default-source/event/presentation-3_aishah-bidin_nuclear-law.pdf?sfvrsn=2.

${ }^{71}$ D. R. Markandu, Roles and Organisation of the NEPIO in Malaysia: Case Study." Paper presented at the Technical Meeting on Topical Issues on Infrastructure Development and Management of National

Capacity for Nuclear Power Program, Vienna, Austria, 2013.

${ }^{72}$ Huu Tan Vuong, Safety Culture in Vietnam." Presentation at the IAEA Technical Meeting on Topical Issues in the Development of Nuclear Power Infrastructure, Vienna, Austria, February 2-6, 2015.

${ }^{73}$ Victor Nian and S. K. Chou, The state of nuclear power two years after Fukushima-The ASEAN perspective, Applied Energy, Vol. 136, 2014, pp. 838-848.

74 Els, Mulder, Preparedness for Disasters Due to Climate Change, 2006, www.climatecentre.org/downloads/files/articles/preparedness\%20for\%20disasters\%20related\%20to\% 20climate \%20change\%20els\%20mulder.pdf.

${ }^{75}$ H. Suntoko and Ismail, Current Status of Siting for NPP in Indonesia, Paper presented at the the Second Workshop on Practical Nuclear Power Plants Construction Experience, Beijing, China, October 24,2013,

www.ansn.iaea.org/Common/Topics/OpenTopic.aspx?ID=13250.

${ }^{76}$ Mely Caballero-Anthony and Julius Cesar I. Trajano, Enhancing nuclear energy cooperation in ASEAN: Regional norms and challenges. Learning from Fukushima: Nuclear power in East Asia, Vol. 44, 2017, pp. 187.

${ }^{77}$ Svetlana, Klyuchanskaya, Nuclear Energy in Southeast Asia and Russia's Interests, Security Index: A Russian Journal on International Security, Vol.18, No. 1, 2012, pp 47-57.

${ }^{78}$ Bambang Sutopo Hadi, BAPETEN Creates Centre of Excellence for Nuclear Security (Bapeten Bentuk Pusat Unggulan Keamanan Nuklir), Antara News, August 19, 2014. 
${ }^{79}$ H. Haditjahyano, Indonesian HRD in Nuclear Security-Batan's Perspective, In Workshop on the Asian Centers of Excellence in Nuclear Nonproliferation and Nuclear Security, Washington, DC, July, Vol. 18. 2014.

${ }^{80}$ M. Sinaga, Development of Nuclear Security in Indonesia, Paper presented at the NRC's International Conference on Nuclear Security, Washington, D.C., December 4-6, 2012.

${ }^{81}$ Disaster Management Division of Prime Minister's Department, Brief Note on the Roles of the National Security Council, Prime Minister's Department as National Disaster Management Organisation

(NDMO), Paper presented at the 3rd ASEAN Inter-Parliamentary Assembly Caucus, Manila, the Philippines, July 1, 2011, www.aipasecretariat.org/wp-content/uploads/2011/07/1.Malaysia-DisasterResponse-Management.pdf.

82 Asian Disaster Reduction Center, Country Report of Malaysia, 2011, www.adrc.asia/nationinformation.php?NationCode=458\&Lang=en\& NationNum=16.

${ }^{83}$ Mohamed Abdul Aziz, Faridah Mohamad Idris, Abu Hassan Husin, and Nasri A. Hamid, Preface: Nuclear Science, Technology and Engineering Conference 2016 (NuSTEC2016), In AIP Conference Proceedings, Vol. 1799, no. 1, 2017.

${ }^{84}$ I. L. Teng, Post Fukushima: Environmental Survey and Public Acceptance on Nuclear Program in Malaysia. Presentation at the International Experts Meeting on Radiation Protection After the Fukushima Daiichi Accident: Promoting Confidence and Understanding, Vienna, Austria, February 21, 2014.

${ }^{85}$ Mely Caballero-Anthony and Julius Cesar I. Trajano, Enhancing nuclear energy cooperation in ASEAN: Regional norms and challenges, Learning from Fukushima: Nuclear power in East Asia Vol.44, 2017, pp. 187.

${ }^{86}$ Ibid.

${ }^{87}$ Ibid, pp. 192.

${ }^{88}$ Ibid. 